\title{
Abundance of Harpy and Crested Eagles from a reservoir-impact area in the Low- and Mid-Xingu River
}

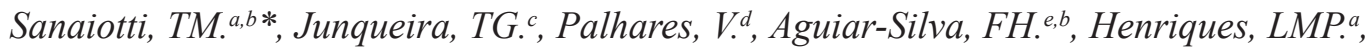 \\ Oliveira, G. ${ }^{d}$, Guimarães, VY. ${ }^{c}$, Castro, $V^{c}$, Mota, D. ${ }^{c}$, Trombin, DF. , Villar, DNA. ${ }^{f}$, \\ Lara, KM. ${ }^{c}$, Fernandes, D. ${ }^{c}$, Castilho, L. ${ }^{c}$, Yosheno, E. ${ }^{c}$, Alencar, RM. ${ }^{c}$, Cesca, L. ${ }^{c}$, \\ Dantas, SM. ${ }^{g}$, Laranjeiras, TO. ${ }^{h}$, Mathias, $P C .{ }^{c}$ and Mendonça, $C V^{c}$ \\ ${ }^{a}$ Coordenação de Pesquisas em Biodiversidade - CBIO, Instituto Nacional de Pesquisas da Amazônia - INPA, \\ Av. André Araújo, 2936, Aleixo, CEP 69067-375, Manaus, AM, Brazil

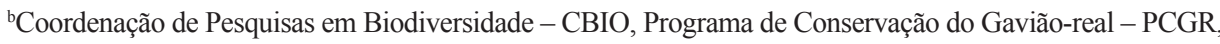 \\ Instituto Nacional de Pesquisas da Amazônia - INPA, Av. André Araújo, 2936, Aleixo, CEP 69067-375, Manaus, AM, Brazil \\ 'BIOTA Projetos e Consultoria Ambiental Ltda, Rua 86C, 64, Setor Sul, CEP 74083-360, Goiânia, GO, Brazil \\ ${ }^{d}$ Leme Engenharia Ltda, Avenida dos Andradas, $3000,11^{\circ}$ ao $13^{\circ}$ andares, \\ Boulevard Corporate Tower Santa Efigênia, CEP 30260-070, Belo Horizonte, MG, Brazil \\ ${ }^{\circ}$ Coordenação de Biodiversidade - CBIO, Programa de Pós-graduação em Ecologia, \\ Instituto Nacional de Pesquisas da Amazônia - INPA, Av. André Araújo, 2936, Aleixo, CEP 69067-375, Manaus, AM, Brazil \\ fSystema Naturae Consultoria Ambiental Ltda, Rua 58, 217, Qd B04, Lt 16, Jardim Goiás, CEP 74810-250, Goânia, GO, Brazil \\ ${ }^{\mathrm{g}}$ Museu Paraense Emilio Goeldi - MPEG, Av. Perimetral, 1901, Terra Firme, CEP 66077-530, Belém, PA, Brazil \\ hInstituto Chico Mendes de Conservação da Biodiversidade - ICMBio, Parque Nacional do Viruá, \\ Rua Alfredo Cruz, 283, Centro, CEP 69301-140, Boa Vista, RR, Brazil \\ *e-mail: tania.sanaiotti@gmail.com
}

Received: June 3, 2014 - Accepted: June 9, 2015 - Distributed: August 31, 2015

(With 2 figures)

\begin{abstract}
In the Brazilian Amazon, two monospecific genera, the Harpy Eagle and Crested Eagle have low densities and are classified by IUCN as Near Threatened due to habitat loss, deforestation, habitat degradation and hunting. In this study, we evaluate occurrence of these large raptors using the environmental surveys database from Belo Monte Hydroelectric Power Plant. Integrating the dataset from two methods, we plotted a distribution map along the Xingu River, including records over a 276-km stretch of river. Terrestrial surveys (RAPELD method) were more efficient for detecting large raptors than standardized aquatic surveys, although the latter were complementary in areas without modules. About $53 \%$ of the records were obtained during activities of wildlife rescue/flushing, vegetation suppression or in transit. Between 2012 and 2014, four Harpy Eagles were removed from the wild; two shooting victims, one injured by collision with power lines and one hit by a vehicle. Also, seven nests were mapped. The mean distance between Harpy Eagle records was $15 \mathrm{~km}$ along the river channel, with a mean of $20 \mathrm{~km}$ between nests near the channel, which allowed us to estimate 20 possible pairs using the alluvial forest, riverine forest and forest fragments. Territories of another ten pairs will probably be affected by inundation of the Volta Grande channel, which is far from the main river. The average distance between Crested Eagle records was $16 \mathrm{~km}$ along the river channel. The only nest found was $1.3 \mathrm{~km}$ away from a Harpy Eagle nest. The remnant forests are under threat of being replaced by cattle pastures, so we recommend that permanently protected riparian vegetation borders (APP) be guaranteed, and that forest fragments within $5 \mathrm{~km}$ of the river be conserved to maintain eagle populations.
\end{abstract}

Keywords: neotropical raptors, Amazon, hydroelectric power plant, environmental impact, Accipitridae.

\section{Abundância de Gavião-real e Gavião-real falso numa área sob impacto de reservatório no Baixo e Médio rio Xingu}

\section{Resumo}

Na Amazônia brasileira dois gêneros mono-específicos, Harpia e Morphnus, caracterizam-se por baixa densidade e estão classificados pelo IUCN como Quase Ameaçados, porém ocorrem sobre grande parte do território nacional, suas principais ameaças são a fragmentação florestal, a degradação de hábitat e a caça. Neste estudo avaliamos a abundância destas duas grandes aves de rapina utilizando a base de dados dos programas ambientais da UHE Belo 
Monte, integrando-se dois métodos para construir um mapa de distribuição ao longo de $245 \mathrm{~km}$ do rio Xingu. Os levantamentos terrestres pelo método RAPELD mostraram-se mais eficientes para os registros de grandes águias quando comparado aos esforços padronizados aquáticos, entretanto estes foram complementares na ausência de módulos. Cinquenta e tres por cento foram registros ocasionais durante a supressão da vegetação, afugentamento ou deslocamento. Entre 2012-2014 quatro harpias foram removidas da natureza, dois indivíduos alvo de disparos, uma por colisão com rede elétrica, e outra por atropelamento. Sete ninhos mapeados, a distância média entre os registros de harpia na calha e margens do rio foi de $15 \mathrm{~km}, 20 \mathrm{~km}$ distância média entre ninhos, o que permitiu estimar um total de 20 casais utilizando as florestas aluviais em uma distancia de $270 \mathrm{~km}$, incluindo matas ciliares e os fragmentos fora da margem do rio. Estimamos que territórios de outros 10 casais usando a Volta Grande longe do rio principal também serão afetados pela inundação. A distância média entre os registros de Morphnus foi $16 \mathrm{~km}$ ao longo do rio, o único ninho mapeado estava distante $1.3 \mathrm{~km}$ do ninho de Harpia. Estes fragmentos florestais estão sendo substituídos por pastagens, ressaltando-se a importância da manutenção das áreas de preservação permanentes (APP) e a proteção destes fragmentos em diversos formatos de áreas de proteção, para diminuir a degradação dos mesmos e garantir a manutenção das populações destes grandes predadores na região do rio Xingu.

Palavras-chave: ave de rapina neotropical, Amazônia, hidroelétrica, impacto ambiental, Accipitridae.

\section{Introduction}

The two largest raptors in the Brazilian Amazon, Harpy Eagle, Harpia harpyja (Linnaeus) and Crested Eagle, Morphnus guianensis (Daudin) occur at low densities and are hard to detect in the rainforest (Ferguson-Lees and Christie, 2001). They occur over much of Brazil, mainly in the Amazon, and the main threats are habitat loss and hunting (Vargas-González et al., 2006). The latter sometimes results from human-wildlife conflicts due to potential livestock predation (e.g., Trinca et al., 2008; DeLuca, 2012). Both species are included in the Near Threatened (NT) category of the IUCN (IUCN, 2014). The Harpy Eagle is listed in Appendix I of the Convention on International Trade in Endangered Species of Wild Fauna and Flora (CITES, 2012). Both are considered as Vulnerable on the Brazilian National List of Endangered Species (Brasil, 2014b). The concern for the species has increased in Amazonia due to environment impacts that result in vegetation removal, which is higher in areas impacted by hydroelectric dams, which also have many other possible adverse effects on the environment (Fearnside, 2006). The Brazilian government plans to build 30 hydroelectric power plants in Amazonia by 2020 (Brasil, 2011).

Álvarez-Cordero (1996) estimated the mean distance between Harpy Eagle nests as $7 \mathrm{~km}$ for forests under timber extraction in Venezuela and about 3-5 km in forests under extractivist use in Panama. In Ecuador, Muñiz-López et al. (2007) reported that the distances between four Harpy Eagle nests ranged from 6.8 to $17 \mathrm{~km}$. In Panama, a study in primary and secondary forest at Darien estimated an average distance between nests as $4.1 \mathrm{~km}$ (range 2.6-6.2 km) (Vargas-González and Vargas, 2011). Aguiar-Silva et al. (2011), working in the Brazilian Amazon, in areas with a mosaic of managed forest, illegal timber extraction and agricultural fields, estimated the average distance between nests as $8 \mathrm{~km}$ (range 5-12 km). In one Ecuadorian locality, the young stayed until two years of age within a radius of $1.3 \mathrm{~km}$ of the nest, within the parents' territory (MuñizLópez et al. 2012).
There are no records of density for the Crested Eagle, but the rare records of this species indicate that it can coexist with Harpy Eagle and that territories of individuals of the two species may overlap. Muñiz-López et al. (2007) found a Crested Eagle nest $2.3 \mathrm{~km}$ from a Harpy Eagle nest. The species use distinct strata to build their nests, with Harpy Eagles using emergent trees (Luz, 2005; Luz et al., 2010), and Crested Eagles using canopy trees (Whitacre et al., 2012; Harpy Eagle Conservation Program in Brazil-PCGR personal archive). Their diets also are distinct: Crested Eagles feed mainly on smaller prey than Harpy Eagles (Soares et al., 2008; Whitacre et al., 2012).

The first reports of Harpy Eagles on the Xingu River come from two centuries ago (Edwards, 1847), but only recently for Crested Eagle (Henriques et al., 2008). Crested Eagle records in the Brazilian Amazon are far more scattered than those of Harpy Eagles. For about 100 nests of Harpy Eagle mapped, there are only 10 of Crested Eagle (Aguiar-Silva et al., 2013, PCGR database).

Both species are part of the Brazilian National Action Plan for Raptors (Soares et al., 2008), National Action Plan for Endemic and Threatened Species from the Low- and Mid-Xingu River - PAN Xingu (Brasil, 2012) and National Action Plan for Amazonian Birds (Brasil, 2014a).

Only one Harpy Eagle nest, which was located on private land, on the border of Brazil Novo and Altamira municipalities, has previously been reported for the PAN Xingu area (Henriques et al., 2008). There were no known nests of the Crested Eagle in the area.

We evaluate the distribution of the species in the area affected by the Belo Monte Hydroelectric Complex, using two complementary methods and compare the efficiency of these methods. We analyzed the databases from the Environmental Impact studies (EIA/RIMA) and the Fauna-Monitoring Project undertaken in the Area of Influence of Belo Monte Hydroelectric Power Plant (UHE), including secondary records generated from other studies, and fauna rescue/flushing during vegetation suppression or in transit, hunting, and records of vehicle collisions, within the area of the PAN Xingu. 


\section{Material and Methods}

The study area included the area of PAN of the Low- and Mid-Xingu River, Pará State, northern Brazil, where the Belo Monte Hydroelectric Complex is being built (Figure 1). According to the international climatic classification system of Köppen, the predominant climate in this region is humid tropical Am, mean air temperature of $26{ }^{\circ} \mathrm{C}$, mean annual rainfall of $2289 \mathrm{~mm}$, and with a short dry season occurring in August and September with average rainfall of $33.4 \mathrm{~mm}$ and $39.3 \mathrm{~mm}$, respectively (IBAMA, 2007). The Xingu River flood season is from December to June. The image prepared for Figure 1 includes information on deforestation up to 2014 (Brasil, 2014c)

Thirty-one km, located between the headwaters of the Paquiçamba River and Belo Monte village of the $276 \mathrm{~km}$ stretch of the Xingu River in the study area, were not sampled due to navigational difficulties. A total of $245 \mathrm{~km}$ was sampled by boat surveys in the same stretch of river in which the terrestrial surveys were distributed.

Different efforts and sample periods were used in the studies included in the database. The terrestrial and aquatic surveys were carried out during the EIA/RIMA in 2000-2002 and 2007-2008 (Henriques et al., 2008). The standardized surveys of the Terrestrial and Aquatic Fauna Monitoring Project were done from February 2012 to March 2014, according to the data available in the Fifth Consolidated Report from Norte Energia to Ibama (Norte Energia, 2014), and continued up to February 2015 (data made available by Biota and Leme). Occasional records were considered up to July 2015.

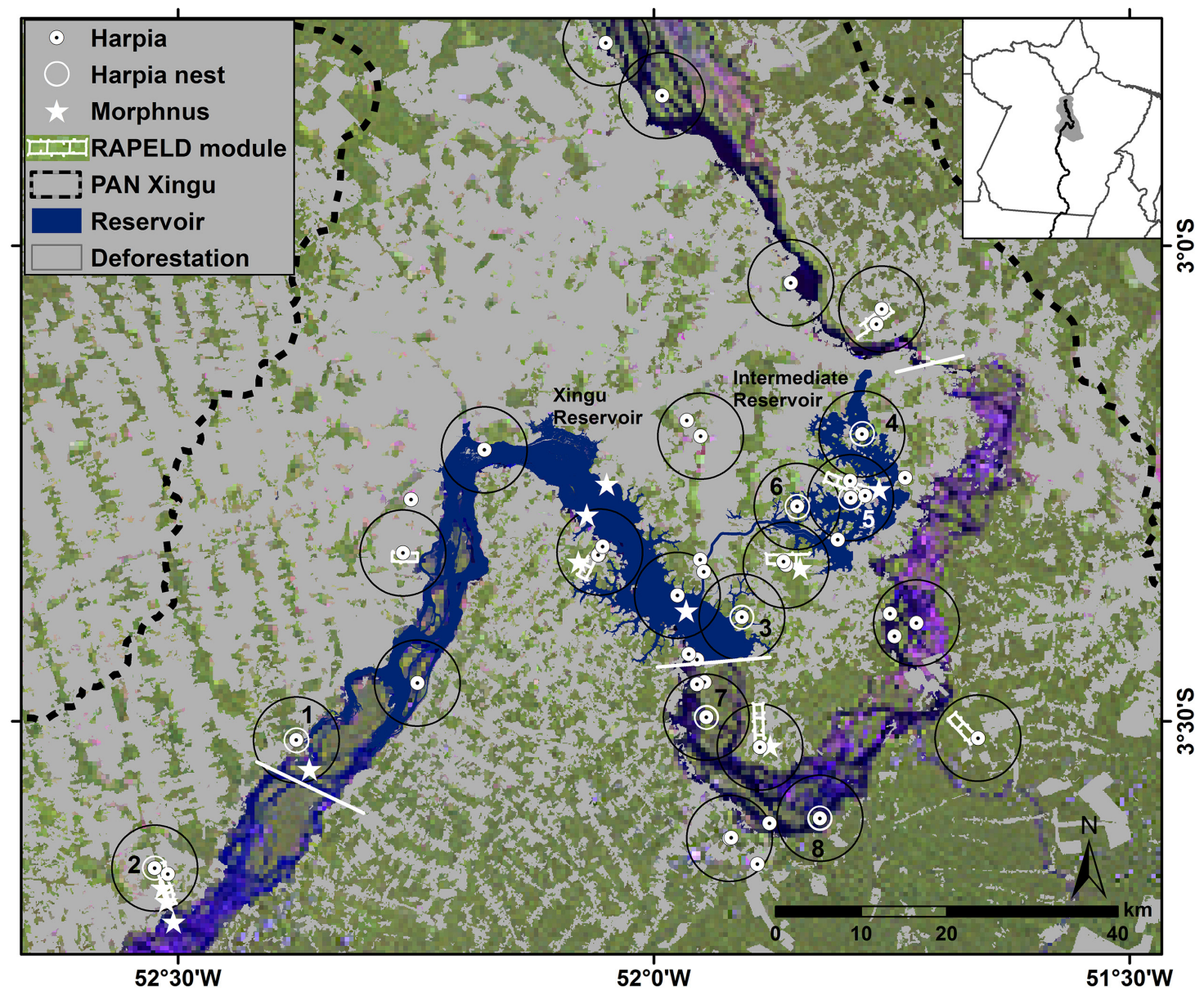

Figure 1. Records of Harpy Eagles and Crested Eagles in the area under the influence of Belo Monte Complex and nests mapped in the area of PAN of the Low- and Mid-Xingu River. The records for Harpy Eagle $(\bullet)$ combined Terrestrial Avifauna survey, Aquatic and Semi-aquatic surveys and Occasional records and (O) nests, and for Crested Eagle ( $\vec{*})$ combined Terrestrial and Aquatic and Semi-aquatic surveys and Occasional records. Harpy Eagle active nests (1) Torrão, (2) Module 1, (3) Xingu Reservoir-CEA, (4) Intermediate Reservoir-55CTCA, (5) Intermediate Reservoir-Ticaruca, (6) Intermediate Reservoir-Paquiçamba; and inactive nests (7) Island-record 32, (8) Island-record 33. Black circles represent 5-km buffers around Harpy Eagle territories. The limits of the four Aquatic sampling areas are shown by straight white lines. The estimated reservoir areas are in black. The inset shows Pará state with the entire area of PAN Xingu highlighted in grey. (Landsat 5 mosaic 2000/deforestation up to 2014, see methods). 


\subsection{Terrestrial-habitat surveys}

The Terrestrial Avifauna surveys between 2012-2015, were distributed in 8 RAPELD (Rapid Assessment Long-Term Ecological Research Program - Magnusson et al., 2005, 2013) modules. This spatial distribution of effort maximizes the probability of sampling biological communities in large areas using small sample areas (Magnusson et al., 2005). The protocol used was two observers walking simultaneously two parallel $5-\mathrm{km}$ transects in each module during three consecutive days, noting visual and acoustic records. The cumulative sample effort in this study is presented as $\mathrm{km}$ walked *day*sampling period. Modules 1, 5 and 7 had 5-km parallel transects, totaling $10 \mathrm{~km}$ walked per day in each module. In the remaining modules, the trails were less than $5 \mathrm{~km}$, so the total distance walked varied among modules $(\mathrm{M} 2=6 \mathrm{~km}$; M3 $=7.5 \mathrm{~km} ; \mathrm{M} 4=8 \mathrm{~km}$; $\mathrm{M} 6=8.5 \mathrm{~km} ; \mathrm{M} 8=9 \mathrm{~km})$. The sampling periods were (1) February to April 2012, (2) August to December 2012, (3) April to June 2013, (4) August to October 2013, (5) January to March 2014, (6) July to August 2014 and (7) January to February 2015. We excluded the first sampling period from the analysis because only 4 of the 8 modules were sampled.

\subsection{Aquatic-habitat surveys}

The Aquatic Surveys during the period 2012-2015 were standardized samples by motorboat for Aquatic and Semi-aquatic Avifauna and Aquatic (Cetacean) and Semi-aquatic Mammals (Mustelid).

\subsubsection{Aquatic and Semi-aquatic Avifauna surveys}

Two protocols of records were combined in this study, totaling $245 \mathrm{~km}$ sampled, in $270 \mathrm{~km}$ of the Xingu River, subdivided into four sampled areas (Figure 1), with two observers over 20 days for each sampling period. The protocols included were (1) boat transects for Qualitative and Quantitative Records, in each of the four areas, 10 transects $8-\mathrm{km}$ long, parallel to each edge when possible, in some cases parallel to an edge and an island (for this study, we considered the linear distance sampled by boat along the river) and (2) boat transects undertaken for Acoustic Point Counts of birds in habitats associated with and/or created by rivers, distributed in five localities within each area (approximately 2-km long), in order to sample one point every $100 \mathrm{~m}$ during 10 minutes, recording sightings and calls, totaling 100 points for each of the four areas of the previous protocol, totaling 400 points. The 13 sampling periods were March-April 2012, June-July 2012, August-September 2012, November-December 2012, January-February 2013, April-May 2013, July-August 2013, October-November 2013, January-February 2014, April-May 2014, July-August 2014, October 2014 and January-February 2015. The cumulative sampling effort for this study was presented as linear kilometers travelled by boat along the river*sampling period.

\subsubsection{Aquatic and Semi-aquatic Mammal (Mustelid) surveys}

The records for this study were combined as for the Avifauna Surveys, considering a total of $245 \mathrm{~km}$ sampled in $270 \mathrm{~km}$ along the Xingu River, subdivided into four sampling areas (Figure 1). However, the number of transects varied among the areas and among 13 sampling periods, accumulating a total of $61,157,149,158,191,98,154$, $154,168,169,167,156,169$ transects per sampling period, respectively. The protocol consisted of two observers for 30 days per sampling period. Sampling periods were March-April 2012, June-July 2012, August-September 2012, November-December 2012, January-February 2013, April-May 2013, July-August 2013, October-November 2013, January-February 2014, April-May 2014, July-August 2014, October-November 2014 and January-February 2015. The cumulative sampling effort for this study will be presented as linear kilometers travelled by boat along the river*sampling period.

Besides the records from the standardized samples, occasional records were included on the map. These included information from the following sources: activities for terrestrial Fauna Rescue/flushing in areas under vegetation suppression between July 2011 and March 2013 over an area of 4030 ha (Norte Energia, 2014); and in areas under suppression between 2014-2015, from photographs or call records, as well as non-documented (visual or acoustic) records during transit among areas. Only precise descriptions of the sighting that allowed us to confirm the species were included, as were records of specimens taken by hunters or hit by vehicles.

We represented territory areas with a $5-\mathrm{km}$ buffer from nests or potential centers.

\section{Results}

There were 58 records of the species in different locations in the area (Harpy Eagle, $n=47$ and Crested Eagle, $\mathrm{n}=11$ (Table 1), of those 27 (47\%) came from standardized surveys and 31 (53\%) from occasional encounters. There were also 13 records made during nest monitoring (3a-d, 34a, 39a-b, 43a, 45a-b, 47a, 58a-b) (Table 1).

\subsection{Harpy Eagles}

Six Harpy Eagles were recorded in the standardized Aquatic Surveys: four from the Aquatic and Semi-aquatic Mammal (Mustelid) Surveys, and two from Aquatic and Semi-aquatic Avifauna monitoring, each survey for a total effort of $245 \mathrm{~km}$ travelled by boat*13 sampling periods (Table 1). The average distance among closer records was $21 \mathrm{~km}(9-28 \mathrm{~km})$ (Figure 1) and one record was made during transit by boat and was categorized as occasional (Table 1, Figure 2a).

Fourteen Harpy Eagles were recorded in the standardized Terrestrial Surveys for a total effort of $69 \mathrm{~km} * 3$ days* 6 sampling periods. Harpy Eagles were recorded in all eight modules, with one nest found in module 1 . 

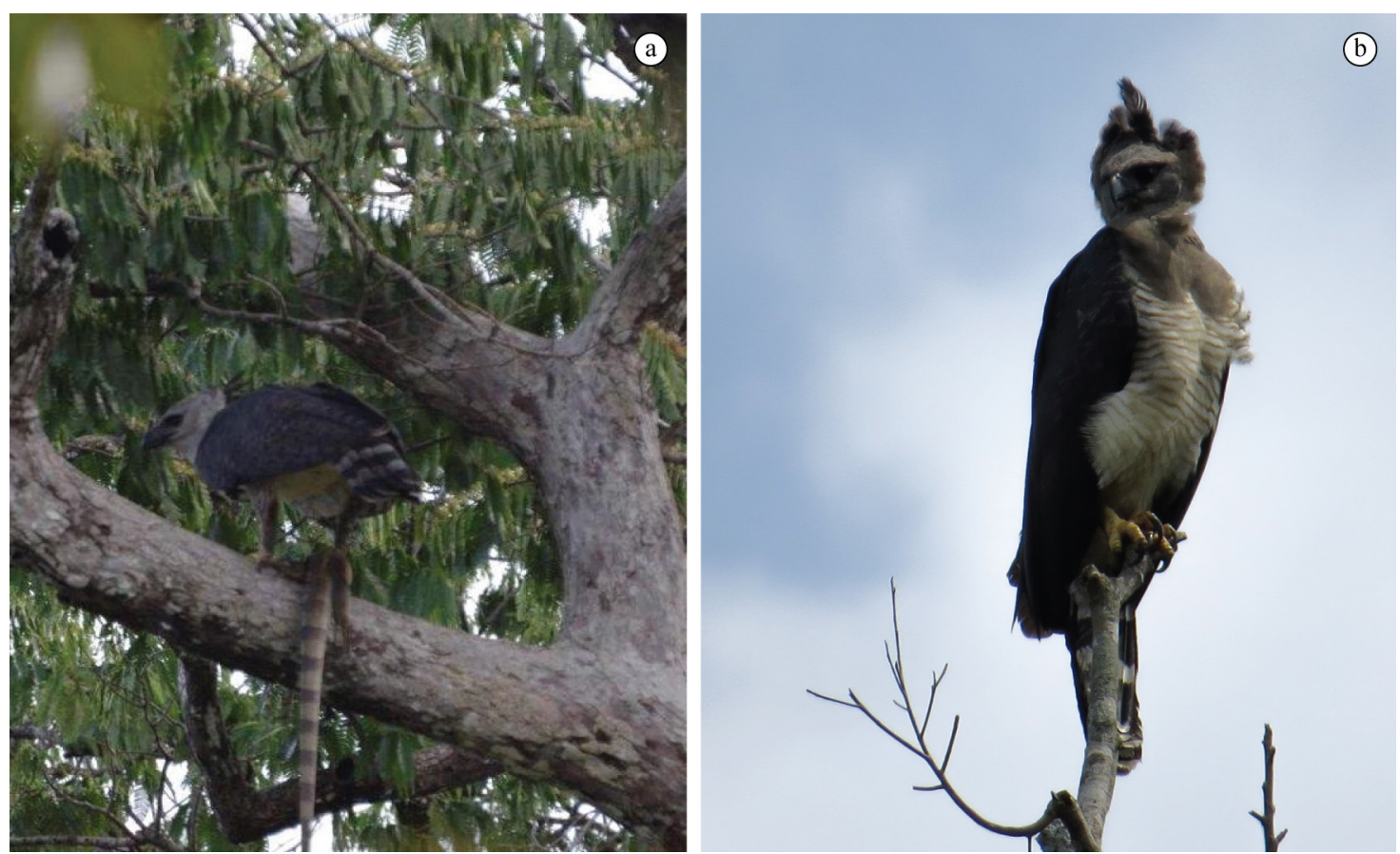

Figure 2. (a) Adult Harpy Eagle feeding on an Iguana iguana seen during an Aquatic avifauna survey (record 11, photo VP Palhares), (b) Adult Crested Eagle pale morph plumage during a Terrestrial Avifauna survey (record 51, photo V Castro).

Thirty Harpy Eagle records were from occasional documented and undocumented records. Between 2001-2002, during avifauna surveys for the EIA/RIMA, one adult Harpy Eagle was reported to have been killed by hunters. An adult male was shot by Xipaia Indians between February and March 2001 in terra firme forest on the left bank of the Xingu River, locality Bom Jardim (Miguel Xipaia farm), Vitória do Xingu municipality (Table 1). According to the indigenous people, the species is hunted to extract the tibia, primary remiges and rectrices, to make arrows (LMPH, Henriques et al., 2008).

Between 2012 and 2014, four Harpy Eagles were removed from the wild because they were hunted or injured. An adult male, which was rescued 6 February 2014 by a Military Policeman from Altamira (C.A. Silva, pers. comm.), on the periphery of Altamira, in a forest at the edge of the road from the airport to the prison, died ten days after being shot. In the necropsy, two 5-mm diameter lead shot were detected by X-ray. At the moment of medical attention it weighed $4.4 \mathrm{~kg}$, and the necropsy revealed enlarged testes, indicating breeding activity. As an environmental crime, a technical report including a shotgun pellet removed from the body was given to the Environmental Agency IBAMA, Belém, No 02018.001564/2014-18 (TMS). This specimen was deposited at the Museu Paraense Emílio Goeldi Bird Collection (MPEG 78231) (Table 1). The second Harpy Eagle individual was found hit by a car 9 March 2012 (DFT) at km 9 of the East-West Via of the diversion channel. Apparently an adult in advanced stage of decomposition, the talons were collected (LC) and maintained at the Environmental Studies Center (CEA).
The hallux measurement (outer curvature chord $=6.1 \mathrm{~cm}$ ) indicated it was a female (Table 1). The third, an adult female Harpy Eagle was rescued on the right bank of the Xingu River after being injured by collision with a power line (Aguiar-Silva et al., 2014b). The fourth record of a hunted individual was confirmed by a photograph of talons that were brought to the village (Aguiar-Silva et al., 2014b) (Table 1).

The active Harpy Eagle nest in a Kapok tree (Ceiba pentandra) mapped during the terrestrial surveys of the EIA/RIMA (Henriques et al., 2008) was monitored from May 2013 by the PCGR in partnership with BIOTA, and has been active since then with successful production of offspring (Aguiar-Silva et al., 2015); a 20-month-old juvenile was still using the nest in July 2015. The nest tree is located on private land and, according to official flooding predictions for the reservoir, the locality is not expected to flood with the filling of the Xingu Reservoir from the Belo Monte Dam, but it will be within the influence area.

Seven new nests of Harpy Eagle were mapped during field work 2014-2015. Two inactive nests on islands downstream of the dam were reported by locals (Aguiar-Silva et al., 2014b) (Table 1). Only one nest was located in the RAPELD module, found during Terrestrial surveys with a flying juvenile (Table 1). The distance between the two active nests (Torrão and module 1) was $18 \mathrm{~km}$ (on the same bank), and the distance between the two inactive nests on islands was about $23 \mathrm{~km}$. Four active nests were mapped during vegetation suppression. All still had juveniles depending on the nest tree in July 2015. Two were on the edge of the area expected to flood when the dam is filled (nest Xingu 
Table 1. Harpy Eagle and Crested Eagle records in the area of the Xingu River. (EIA/RIMA) Environmental Impact Studies; (PCGR) Harpy Eagle Conservation Program in Brazil; (Biota) Biota Projetos e Consultoria Ambiental Ltda.; (Leme) LEME Engenharia; (Arcadis/Naturae) Arcadis Logos/Systema Naturae Consultoria Ambiental LTDA; (WA) www.wikiaves.com; (MPEG) Museu Paraense Emilio Goeldi; (Pers. arch.) Personal archive.

\begin{tabular}{cccc}
$\begin{array}{c}\text { Record No.) Author of } \\
\text { Record }\end{array}$ & Record description & $\begin{array}{c}\text { Record } \\
\text { date/mo/year }\end{array}$ & Reference \\
\hline
\end{tabular}

\section{HARPY EAGLE}

Photograph of an adult killed in the locality Bom Jardim

(1) LMP Henriques

(Miguel Xipaia farm), left bank of the Xingu River A3 of EIA/

Feb-Mar/2001 Henriques et al. (2008)

RIMA, municipality of Vitória do Xingu.

Sighting of an adult, left bank,

(2) LMP Henriques, SM Dantas locality Bom Jardim, A3 of EIA RIMA, municipality of Anapu.

Apr/2008 Henriques et al. (2008) Photograph of an adult found

(3) TO Laranjeiras, LMP Henriques, SM Dantas in nest tree, locality Torrão, A1 of EIA/RIMA, municipality of

15/Apr/2008, Jul/2008 Henriques et al. (2008) Brazil Novo.

(3a) TM Sanaiotti; TG Junqueira

Torrão nest monitoring and photograph of adult in the nest (same as 3).

Torrão nest monitoring and

(3b) TM Sanaiotti; TG Junqueira; V Palhares photograph of the young about five months old.

(3c) K Lara, TG Junqueria, FH Aguiar-Silva, Olivier Jaudoin Photograph of the juvenile from the Torrão nest during nest monitoring (same as 3).

Photograph of the juvenile from the Torrão nest during nest 06/07/2015 Biota

(3d) TG Junqueira, Denilson Aranha monitoring (same as 3).

19/05/2013 PCGR; Biota

23/03/2014 PCGR; Biota; Leme Photograph of a juvenile feeding on a Coendou sp., Serra Island.

(4) DF Trombin

Photograph of an adult at Serra

(5) José Pezzi Island, area under dam impact Canteiro de Obras Pimental.

(6) DF Trombin Sighting of an adult, Pimental Island.

11/07/2014 Biota/ WA1576552

WA1569328

Photograph of a juvenile about

(7) DF Trombin 3 yrs old, attacking a group of Alouatta sp. during flushing.

Photograph of a sub-adult during Mustelid survey

(8) DAN Villar (PMASA), A3, Bela Vista Island, passing the Mucura Waterfall, above waterfall.

Photograph of an adult female, during Mustelid survey

(9) DAN Villar (PMASA) A4, Porto Seguro
30/10/2012 Consolidate Report

\section{Biota, $6^{\text {th }}$ Technical} IBAMA

Dec/2012 Biota

17/09/2012 Biota

20/09/2013 Biota, WA1119175

Leme C5A3-27012013/

Naturae, $6^{\text {th }}$ Technical

Consolidated Report/

IBAMA

Leme C5A4-30012013/

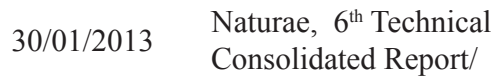

IBAMA Island, between Viola and Santa Clara streams. 
Table 1. Continued...

\begin{tabular}{|c|c|c|c|}
\hline $\begin{array}{c}\text { (Record No.) Author of } \\
\text { Record }\end{array}$ & Record description & $\begin{array}{c}\text { Record } \\
\text { date/mo/year }\end{array}$ & Reference \\
\hline (10) DAN Villar & $\begin{array}{l}\text { Photograph of an adult } \\
\text { female, during Mustelid suvey } \\
\text { (PMASA) A2, Arapuja Island. }\end{array}$ & $13 / 02 / 2013$ & $\begin{array}{l}\text { Leme C5A2-13022013/ } \\
\text { Naturae10, } 6^{\text {th }} \text { Technical } \\
\text { Consolidated Report/ } \\
\text { IBAMA }\end{array}$ \\
\hline $\begin{array}{l}\text { (11) V Palhares, Vicente } \\
\text { Medeiros }\end{array}$ & $\begin{array}{l}\text { Photograph of an adult female } \\
\text { feeding on Iguana iguana, } \\
\text { during Aquatic surveys. } \\
\text { The Avifauna Aquatic/semi } \\
\text { (PAASA), A4, left bank Volta } \\
\text { do Tubarão. }\end{array}$ & $28 / 04 / 2013$ & $\begin{array}{l}\text { Leme/TRQQ-6-4-T9, } 6^{\text {th }} \\
\text { Technical Consolidated } \\
\text { Report/IBAMA }\end{array}$ \\
\hline (12) TG Junqueira & $\begin{array}{l}\text { One remige feather found } \\
\text { during the Terrestrial survey, } \\
\text { M5, connecting trail T1-T2 at } \\
5000 \mathrm{~m} \text {. }\end{array}$ & $23 / 09 / 2013$ & Biota \\
\hline (13) D Fernandes & $\begin{array}{l}\text { Photograph of a pair in the same } \\
\text { tree, and photograph of the male } \\
\text { during complementary study at } \\
\text { Taboca Island. }\end{array}$ & $24 / 10 / 2013$ & $\begin{array}{l}\text { Biota, WA1132221, } \\
\text { WA1132215 }\end{array}$ \\
\hline (14) G Oliveira & $\begin{array}{l}\text { Sighting of adult perched on } \\
\text { the beach and flight to a tree at } \\
\text { Fazenda Island, during aquatic } \\
\text { transit in A3. }\end{array}$ & $02 / 11 / 2013$ & $\begin{array}{l}\text { Leme/C8A3-021113, } 6^{\text {th }} \\
\text { Technical Consolidated } \\
\text { Report/IBAMA }\end{array}$ \\
\hline (15) Rodolfo B Santos & $\begin{array}{l}\text { Photograph of juvenile, during } \\
\text { vegetation supression, at Dicks } \\
\text { and Channels area. }\end{array}$ & $22 / 06 / 2013$ & Biota \\
\hline (16) Frederico A Raul & $\begin{array}{l}\text { Photograph of adult, in } \\
\text { phenology monitoring area, } \\
\text { Travessão } 27 .\end{array}$ & $24 / 01 / 2014$ & Biota \\
\hline (17) D Fernandes, L Castilho & $\begin{array}{l}\text { Photograph of adult calling for } \\
\text { few days at same place, during } \\
\text { Terrestrial surveys M6T1 P3. }\end{array}$ & $28 / 01 / 2014$ & $\begin{array}{l}\text { Biota, WA1231122, } \\
\text { calling WA1234862, } \\
\text { WA1263052 }\end{array}$ \\
\hline $\begin{array}{l}\text { (18) Roberta E Silva, Ricardo } \\
\text { V Leone }\end{array}$ & $\begin{array}{l}\text { Photograph of adult during } \\
\text { Mustelid survey (PMASA) A2. }\end{array}$ & $27 / 01 / 2014$ & $\begin{array}{l}\text { Leme/C9A2-27-114, } 6^{\text {th }} \\
\text { Technical Consolidated } \\
\text { Report/IBAMA }\end{array}$ \\
\hline $\begin{array}{l}\text { (19) V Castro, L Castilho, } \\
\text { Denilson Aranha }\end{array}$ & $\begin{array}{l}\text { Photograph of adult after } \\
\text { playback, during Terrestrial } \\
\text { survey } \mathrm{M} 7, \mathrm{~T} 2, \mathrm{P} 4, \text { and another } \\
\text { same day }(5744) \text {. }\end{array}$ & $31 / 01 / 2014$ & $\begin{array}{l}\text { Biota (V Castro pers. arch. } \\
5724,5744)\end{array}$ \\
\hline (20) V Castro & $\begin{array}{l}\text { Photograph of adult calling } \\
\text { perched on broken tree, } \\
\text { during Terrestrial survey, M4, } \\
\text { connecting trail T1-T2 at } 3500 \\
\text { m, municipality of Anapu. }\end{array}$ & $28 / 02 / 2014$ & Biota/ WA1258949 \\
\hline (21) V Castro, Denilson Aranha & $\begin{array}{l}\text { Sighting of young calling right } \\
\text { after flight during Terrestrial } \\
\text { survey M3, T2, } 1550 \mathrm{~m} \text { and } \\
1000 \mathrm{~m} \text { on the next day (8). }\end{array}$ & $07 / 02 / 2014$ & Biota \\
\hline (22) $\mathrm{R}$ de M Alencar & $\begin{array}{l}\text { Calling during Terrestrial survey } \\
\text { M2, T2, between P2P3. }\end{array}$ & $21 / 03 / 2014$ & Biota \\
\hline (23) D Trombin, L Cesca & $\begin{array}{l}\text { Hit by vehicle, late postmortem } \\
\text { collected and maintained the } \\
\text { claws at CEA, apparently an } \\
\text { adult female. }\end{array}$ & $19 / 03 / 2014$ & Biota \\
\hline
\end{tabular}


Table 1. Continued...

\begin{tabular}{|c|c|c|c|}
\hline $\begin{array}{c}\text { (Record No.) Author of } \\
\text { Record } \\
\end{array}$ & Record description & $\begin{array}{c}\text { Record } \\
\text { date/mo/year }\end{array}$ & Reference \\
\hline $\begin{array}{l}\text { (24) Wesley Barella; Rogerio } \\
\text { Miranda }\end{array}$ & $\begin{array}{l}\text { Sighting during technical visit } \\
\text { of IBAMA in the Channel and } \\
\text { Dicks area - km3, Intermediate } \\
\text { Reservoir. }\end{array}$ & $21 / 03 / 2014$ & Leme; Norte Energia \\
\hline $\begin{array}{l}\text { (25) Cesar A Silva, Emil } \\
\text { Hernandez, VY Guimarães, L } \\
\text { Cesca }\end{array}$ & $\begin{array}{l}\text { An adult male injured, rescued } \\
\text { by the Military Police close } \\
\text { to the jail in Altamira, on } \\
06 / 02 / 2014 \text {, on } 07 / 2 \text { handed } \\
\text { to UFPA, on the same day } \\
\text { handed over for medical care } \\
\text { by Biota, died on } 17 / 02 / 2014 \text {, } \\
\text { and deposited at the MPEG Bird } \\
\text { Collection } \# 78231 \text {. }\end{array}$ & $06 / 02 / 2014$ & This study \\
\hline (26) Igor Martins & $\begin{array}{l}\text { Sighting one individual with } \\
\text { Bradypus, during vegetation } \\
\text { supression in the area under } \\
\text { building impact from Canteiro } \\
\text { de Obras Bela Vista. }\end{array}$ & Apr/2014 & Biota \\
\hline (27) Igor Martins & $\begin{array}{l}\text { Sighting at the same place as } \\
\text { record } 26 \text { with Sapajus apella, } \\
\text { during vegetation suppression } \\
\text { of the vegetation in the area of } \\
\text { Canteiro de Obras Bela Vista. }\end{array}$ & May/2014 & Biota \\
\hline $\begin{array}{l}\text { (28) V Palhares, Gregório } \\
\text { Menezes }\end{array}$ & $\begin{array}{l}\text { Photograph of an adult perched } \\
\text { during Aquatic surveys. } \\
\text { The Avifauna Aquatic/semi } \\
\text { (PAASA), A4. }\end{array}$ & $10 / 04 / 2014$ & $\begin{array}{l}\text { Leme/ C10A4-10042014 } \\
\text { _TRQQ-10-4-T5 }\end{array}$ \\
\hline (29) Mauricio AM Soares & $\begin{array}{l}\text { Photograph of talons from } \\
\text { an adult female killed in the } \\
\text { region of Itatá River, the right } \\
\text { bank tributary of Xingu River, } \\
\text { municipality of Senador José } \\
\text { Porfírio. }\end{array}$ & Nov/2011 & Aguiar-Silva et al. (2014b) \\
\hline (30) Belo Sun Team & $\begin{array}{l}\text { An adult female injured } \\
\text { by collision with power } \\
\text { line, rescued by Sebastião } \\
\text { Nascimento on the road to Itatá } \\
\text { River, municipality of Senador } \\
\text { José Porfírio, medical care by } \\
\text { veterinarians from Arcadis/ } \\
\text { Naturae and released at the } \\
\text { same site by FHAS. }\end{array}$ & $18 / 06 / 2014$ & Aguiar-Silva et al. (2014b) \\
\hline $\begin{array}{l}\text { (31) FH Aguiar-Silva, Olivier } \\
\text { Jaudoin, Cicero Miranda }\end{array}$ & $\begin{array}{l}\text { Sighting of an adult male } \\
\text { crossing a road carrying prey } \\
\text { during monitoring of a release } \\
\text { female, municipality of Senador } \\
\text { José Porfírio. }\end{array}$ & $05 / 07 / 2014$ & Aguiar-Silva et al. (2014b) \\
\hline $\begin{array}{l}\text { (32) FH Aguiar-Silva, Olivier } \\
\text { Jaudoin }\end{array}$ & $\begin{array}{l}\text { Report by locals of a nesting } \\
\text { site in an island about } 2012 \text { in } \\
\text { a Kapok tree, municipality of } \\
\text { Senador José Porfírio. }\end{array}$ & $10 / 07 / 2014$ & Aguiar-Silva et al. (2014b) \\
\hline
\end{tabular}


Table 1. Continued...

\begin{tabular}{|c|c|c|c|}
\hline $\begin{array}{c}\text { (Record No.) Author of } \\
\text { Record }\end{array}$ & Record description & $\begin{array}{c}\text { Record } \\
\text { date/mo/year }\end{array}$ & Reference \\
\hline $\begin{array}{l}\text { (33) FH Aguiar-Silva, Olivier } \\
\text { Jaudoin }\end{array}$ & $\begin{array}{l}\text { Report by locals of a nesting } \\
\text { site in an island about } 2012 \text { in } \\
\text { a Kapok tree, municipality of } \\
\text { Senador José Porfírio. }\end{array}$ & $10 / 07 / 2014$ & Aguiar-Silva et al. (2014b) \\
\hline $\begin{array}{l}\text { (34) G Oliveira, Marcelo } \\
\text { Ribeiro }\end{array}$ & $\begin{array}{l}\text { Photograph of an active nest } \\
\text { on the edge of the Intermediate } \\
\text { Reservoir-Trav55-CTCA. }\end{array}$ & $17 / 07 / 2014$ & Leme, Norte Energia \\
\hline $\begin{array}{l}\text { (34a) FH Aguiar-Silva, Olivier } \\
\text { Jaudoin; Ismael Martins }\end{array}$ & $\begin{array}{l}\text { Photograph of a juvenile and an } \\
\text { adult perched near the nest tree } \\
\text { (same as } 34 \text { ). }\end{array}$ & $15 / 03 / 2015$ & PCGR; Arcadis/Naturae \\
\hline (35) D Mota & $\begin{array}{l}\text { Sighting of an adult perched } \\
\text { during Terrestrial survey } \mathrm{M} 1 \text {, } \\
\mathrm{T} 2,3600 \mathrm{~m} \text {. }\end{array}$ & $05 / 08 / 2014$ & Biota \\
\hline (36) V Castro & $\begin{array}{l}\text { Sighting one of a pair calling } \\
\text { about } 1 \mathrm{~km} \text { apart, one calling } \\
\text { and the other individual } \\
\text { responding from the forest } \\
\text { border, during Terrestrial survey } \\
\mathrm{M} 8, \mathrm{~T} 1,4000 \mathrm{~m} \text {. }\end{array}$ & $17 / 08 / 2014$ & Biota \\
\hline (37) V Castro & $\begin{array}{l}\text { Photograph of a sub-adult } \\
\text { perched, while another was } \\
\text { calling but not seen during } \\
\text { Terrestrial survey M3, T1, } 1000 \\
\text { m. }\end{array}$ & $24 / 07 / 2014$ & $\begin{array}{l}\text { Biota / WA1597922/ } \\
\text { WA1395012 }\end{array}$ \\
\hline (38) K Lara, D Mota & $\begin{array}{l}\text { Photograph of an adult perched, } \\
\text { during Terrestrial survey M7, } \\
\text { T2, P1. }\end{array}$ & $17 / 01 / 2015$ & Biota / WA1610821 \\
\hline (39) TG Junqueira & $\begin{array}{l}\text { Photograph of a juvenile } \\
\text { carrying a Brazil Nut fruit in the } \\
\text { new nest mapped (Module 1), } \\
\text { during Terrestrial survey M1, } \\
\text { T1, } 3500 \mathrm{~m} \text {. }\end{array}$ & $29 / 01 / 2015$ & $\begin{array}{l}\text { Biota / WA1625209 / } \\
\text { WA1625204 }\end{array}$ \\
\hline (39a) D Mota & $\begin{array}{l}\text { Photograph of an adult male } \\
\text { bringing a Coendu prehensilis } \\
\text { tail to the nest to feed the } \\
\text { juvenile that was at the nest } \\
\text { (same as record 39) during nest } \\
\text { monitoring M1, T1, 3500 m. }\end{array}$ & $31 / 01 / 2015$ & Biota / WA1610818 \\
\hline $\begin{array}{l}\text { (39b) TM Sanaiotti; TG } \\
\text { Junqueira, Denilson Aranha }\end{array}$ & $\begin{array}{l}\text { Photograph of the juvenile at the } \\
\text { nest tree and an adult bringing } \\
\text { a Bradypus variegatus to a } \\
\text { tree near the nest (same as } 39 \text { ) } \\
\text { during nest monitoring } \mathrm{M} 1, \mathrm{~T} 1 \text {, } \\
3500 \mathrm{~m} \text {. }\end{array}$ & $05 / 07 / 2015$ & PCGR; Biota \\
\hline (40) D Mota & $\begin{array}{l}\text { Photograph of an adult female } \\
\text { crossing trail during Terrestrial } \\
\text { survey } \mathrm{M} 8, \mathrm{~T} 2,4300 \mathrm{~m} \\
\text { probably same individual as } \\
\text { record } 36 .\end{array}$ & $10 / 02 / 2015$ & Biota / WA1610823 \\
\hline (41) E Yosheno, D Mota & $\begin{array}{l}\text { Photograph of a juvenile } \\
\text { perched during Terrestrial } \\
\text { survey M6, T1, P4. }\end{array}$ & $17 / 02 / 2015$ & Biota / WA1613831 \\
\hline
\end{tabular}


Table 1. Continued...

\begin{tabular}{|c|c|c|c|}
\hline $\begin{array}{c}\text { (Record No.) Author of } \\
\text { Record }\end{array}$ & Record description & $\begin{array}{c}\text { Record } \\
\text { date/mo/year }\end{array}$ & Reference \\
\hline $\begin{array}{l}\text { (42) V Palhares, Fredson } \\
\text { Caitano, Marcelo Ribeiro }\end{array}$ & $\begin{array}{l}\text { Photograph of an adult feeding } \\
\text { on Iguana iguana, during transit } \\
\text { between sites. }\end{array}$ & $09 / 03 / 2015$ & Leme / T27-09032015 \\
\hline $\begin{array}{l}\text { (43) FH Aguiar-Silva, Olivier } \\
\text { Jaudoin; Carlos ED Cintra; } \\
\text { Roberto Silva }\end{array}$ & $\begin{array}{l}\text { Active nest mapped on the edge } \\
\text { of Xingu Reservoir - CEA, } \\
\text { female incubating. }\end{array}$ & $15 / 03 / 2015$ & $\begin{array}{l}\text { PCGR; Arcadis/Naturaes; } \\
\text { NE }\end{array}$ \\
\hline $\begin{array}{l}\text { (43a) TM Sanaiotti; Ralder F } \\
\text { Rossi }\end{array}$ & $\begin{array}{l}\text { Photograph of female and } \\
\text { nestling about } 2 \text { months old } \\
\text { in the nest (same as } 43 \text { ), prey } \\
\text { remains found under the isolated } \\
\text { nest tree. }\end{array}$ & 06/07/2015 & PCGR; Arcadis/Naturae \\
\hline $\begin{array}{l}\text { (44) V Palhares, Marcelo } \\
\text { Ribeiro }\end{array}$ & $\begin{array}{l}\text { Photograph of an adult with } \\
\text { alert behavior, moving around, } \\
\text { during vegetation supression at } \\
\text { Intermediate Reservoir-Ticaruca } \\
\text { (near record 45). }\end{array}$ & $17 / 04 / 2015$ & $\begin{array}{l}\text { Leme/ RI } \\
\text { PENHA_17042015 }\end{array}$ \\
\hline $\begin{array}{l}\text { (45) Danielle A Siva, Valerlan } \\
\text { Conceição, Paulo Ferreira, } \\
\text { Daniel Eskavron, Sebastião } \\
\text { Rocha, Jose Pereira; Marcelo } \\
\text { Ribeiro }\end{array}$ & $\begin{array}{l}\text { Photograph of an active nest } \\
\text { found at Intermediate Reservoir- } \\
\text { Ticaruca during vegetation } \\
\text { suppression (Penha); date } \\
\text { filming nestling about } 3 \text { months } \\
\text { old inside the nest. }\end{array}$ & $\begin{array}{l}27 / 04 / 2015 \\
30 / 04 / 2015\end{array}$ & Arcadis/Naturae; Leme \\
\hline $\begin{array}{l}\text { (45a) Ralder F Rossi; Danielle } \\
\text { A Silva }\end{array}$ & $\begin{array}{l}\text { Photograph of an adult and } \\
\text { nestling inside the nest at } \\
\text { Intermediate Reservoir-Ticaruca } \\
\text { (same as 45); date juvenile left } \\
\text { nest with flying difficulties. }\end{array}$ & $\begin{array}{l}13 / 05 / 2015 \\
22 / 06 / 2015\end{array}$ & Arcadis/Naturae \\
\hline $\begin{array}{l}\text { (45b) TM Sanaiotti; Ralder F } \\
\text { Rossi }\end{array}$ & $\begin{array}{l}\text { Photograph of a juvenile } \\
\text { perched on a cut tree trunk } \\
\text { near the ground by the isolated } \\
\text { nest Intermediate Reservoir- } \\
\text { Ticaruca, (same as } 45 \text { ). It } \\
\text { flew } 130 \mathrm{~m} \text { to another cut } \\
\text { tree. Reinstalling perches } \\
\text { near forest remnants has been } \\
\text { recommended by TMS to NE as } \\
\text { a mitigation action. }\end{array}$ & $06 / 07 / 2015$ & PCGR; Arcadis/Naturae \\
\hline (46) Bruna K Braun & $\begin{array}{l}\text { One remige feather found } \\
\text { during Rescue activities, about } \\
1 \mathrm{~km} \text { from the nest Intermediate } \\
\text { Reservoir-Paquiçamba (record } \\
47 \text { ). }\end{array}$ & 01/07/2015 & Arcadis/Naturae \\
\hline $\begin{array}{l}\text { (47) Cristiane RD Vieira, } \\
\text { Marcos Ramalho, Elson Lima, } \\
\text { Alciomar Araujo Wanderley } \\
\text { Eskavron }\end{array}$ & $\begin{array}{l}\text { Active nest Intermediate } \\
\text { Reservoir-Paquiçamba found } \\
\text { during vegetation suppression } \\
\text { (Willy). Adult observed several } \\
\text { days in the tree since the found } \\
\text { and juvenile only once. }\end{array}$ & $\begin{array}{l}10 / 06 / 2015 \\
01 / 07 / 2015\end{array}$ & Arcadis/Naturae \\
\hline
\end{tabular}


Table 1. Continued...

\begin{tabular}{|c|c|c|c|}
\hline $\begin{array}{c}\text { (Record No.) Author of } \\
\text { Record }\end{array}$ & Record description & $\begin{array}{c}\text { Record } \\
\text { date/mo/year }\end{array}$ & Reference \\
\hline \multirow[t]{2}{*}{$\begin{array}{l}\text { (47a) TM Sanaiotti; Ralder F } \\
\text { Rossi }\end{array}$} & $\begin{array}{l}\text { Photograph of prey remains } \\
\text { under the isolated nest } \\
\text { Intermediate Reservoir- } \\
\text { Paquiçamba (same as } 47 \text { ), also } \\
\text { feces on leaves and ground, } \\
\text { evidence of use of the nest by } \\
\text { juvenile and adults. }\end{array}$ & $06 / 07 / 2015$ & PCGR; Arcadis/Naturae \\
\hline & CRESTED EAGLE & & \\
\hline (48) LMP Henriques & $\begin{array}{l}\text { Sighting, Day list, A2 of EIA/ } \\
\text { RIMA, Taboca Island. }\end{array}$ & 2000 & LMP Henriques pers. arch. \\
\hline (49) LMP Henriques & $\begin{array}{l}\text { Sighting of adult during Aquatic } \\
\text { survey from EIA/RIMA, at A2, } \\
\text { census } 19, \text { T6. }\end{array}$ & $23 / 04 / 2008$ & LMP Henriques pers. arch. \\
\hline $\begin{array}{l}\text { (50) V Palhares, Dorinny } \\
\text { Lisboa, José L Paula }\end{array}$ & $\begin{array}{l}\text { Sighting of adult in flight, } \\
\text { during Listening Point Aquatic } \\
\text { and Semi-aquatic Avifauna } \\
\text { survey A1, nearby Limão } \\
\text { locality, below Travessão } 17 .\end{array}$ & $31 / 03 / 2012$ & Leme/PE-1-1-L1 \\
\hline (51) V Castro & $\begin{array}{l}\text { Photograph adult pale morph } \\
\text { plumage, during Terrestrial } \\
\text { survey M5, T2. }\end{array}$ & $20 / 09 / 2013$ & $\begin{array}{l}\text { Biota/ WA1091967, } \\
\text { WA1221499 }\end{array}$ \\
\hline $\begin{array}{l}\text { (52) TM Sanaiotti; TG } \\
\text { Junqueira; V Palhares }\end{array}$ & $\begin{array}{l}\text { Sighting adult pale morph } \\
\text { plumage during Aquatic transit } \\
\text { to Harpy Eagle nest Torrão. }\end{array}$ & $23 / 03 / 2014$ & PCGR; Biota; Leme \\
\hline $\begin{array}{l}\text { (53) Roberta E Silva; Cesar } \\
\text { Leite }\end{array}$ & $\begin{array}{l}\text { Photograph of an adult pale } \\
\text { morph plumage perched during } \\
\text { Semi-aquatic Mustelid survey, } \\
\text { A2, right bank, Cajueiro Island. }\end{array}$ & $04 / 05 / 2014$ & RE Silva pers. arch.; Leme \\
\hline (54) V Castro, L Castilho & $\begin{array}{l}\text { Sighting of adult pale morph } \\
\text { plumage perched, that } \\
\text { approximate after playback } \\
\text { during, during Terrestrial survey } \\
\text { M1, T1, 500m. }\end{array}$ & 03/08/2014 & Biota \\
\hline (55) Jailson Xavier & $\begin{array}{l}\text { Sighting of adult pale morph } \\
\text { plumage perched, during } \\
\text { Terrestrial survey M7, T2, near } \\
\text { P1. }\end{array}$ & $19 / 08 / 2014$ & Biota \\
\hline (56) V Castro, E Yosheno & $\begin{array}{l}\text { Photograph of an adult extreme } \\
\text { dark morph plumage perched } \\
\text { during Terrestrial survey M6, } \\
\text { T1. }\end{array}$ & $16 / 02 / 2015$ & Biota / WA1612590 \\
\hline (57) TG Junqueira, K Lara & $\begin{array}{l}\text { Photograph of an adult pale } \\
\text { morph plumage perched, during } \\
\text { Terrestrial survey M3, T1, P3. }\end{array}$ & $24 / 02 / 2015$ & Biota / WA1622326 \\
\hline (58) Jailson Xavier & $\begin{array}{l}\text { Active nest found during } \\
\text { Herpetofauna survey at } \mathrm{M} 1, \mathrm{~T} 1 \text {, } \\
2150 \mathrm{~m} \text {. }\end{array}$ & 09/03/2015 & Biota \\
\hline $\begin{array}{l}\text { (58a) FH Aguiar-Silva, Olivier } \\
\text { Jaudoin; TG Junqueira, } \\
\text { Denilson Aranha }\end{array}$ & $\begin{array}{l}\text { Photograph of two adults pale } \\
\text { morph plumage and one chick } \\
\text { one week old in the nest (same } \\
\text { as 58). }\end{array}$ & $14 / 03 / 2015$ & PCGR; Biota \\
\hline $\begin{array}{l}\text { (58b) TM Sanaiotti; TG } \\
\text { Junqueira, Denilson Aranha }\end{array}$ & $\begin{array}{l}\text { Photograph of juvenile perched } \\
\text { on a tree near the nest (same as } \\
58 \text { ). }\end{array}$ & $06 / 07 / 2015$ & PCGR; Biota \\
\hline
\end{tabular}


Reservoir-CEA with a two-month-old nestling, and nest Intermediate Reservoir-55CTCA with a flying juvenile) and two, already isolated by the vegetation suppression, will be inundated (nest Intermediate Reservoir Ticaruca with a juvenile about six months old but with perching behavior changed because of the surrounding vegetation suppression where mitigation action is required, and nest Intermediate Reservoir Paquiçamba with a flying juvenile) (Table 1, Figure1).

\subsection{Crested Eagles}

Of the 11 Crested Eagle records, two were found during the EIA/RIMA; one in 2000 during qualitative records on an island and the other on 23 April 2008 during Aquatic Surveys. Eight records came from the surveys from 2012-2015. During the Aquatic Avifauna Surveys, there were two records, and another record was made during transit by boat and was categorized as occasional (Table 1 , Figure 2b). Five records were made during Terrestrial Surveys, recorded in 5 of 8 modules, one classified as occasional was when the nest was found $1.3 \mathrm{~km}$ from an active Harpy Eagle nest in the same module 1 (Table 1).

\subsection{Comparison between species}

A comparison of the RAPELD and Aquatic transects methods was carried out for the total extent of areas 1-3 and partially for area 4 (restricted to the first $19 \mathrm{~km}$ where module 8 is located). The effort used for each method was compared with the number of records for both species. The Terrestrial surveys revealed 14 Harpy Eagles in $69 \mathrm{~km}$ walked*3 days*6 sampling periods, and six Harpy Eagles from the Aquatic standardized methods combined. Mustelid surveys recorded four in $245 \mathrm{~km}$ travelled by boat*13 sampling periods; and Avifauna surveys recorded two in $245 \mathrm{~km}$ travelled by boat*13 sampling periods. Five Crested Eagles were recorded in $69 \mathrm{~km}$ walked*3 days* 6 sampling periods by Terrestrial surveys, and the Aquatic standardized methods recorded two individuals, both from Avifauna monitoring of $245 \mathrm{~km}$ travelled by boat*13 sampling periods.

The combined records, terrestrial, aquatic and occasional, along the river $(n=58)$, allowed us to estimate an average of one Harpy Eagle per $15 \mathrm{~km}$ and one Crested Eagle per $16 \mathrm{~km}$ of river surveyed (including terrestrial records up to $5 \mathrm{~km}$ from the margin).

Harpy Eagle combined records $(\mathrm{n}=47)$ from all surveys Aquatic and Terrestrial, and also Aquatic occasional records (excluding 6 Terrestrial occasional $>5 \mathrm{~km}$ from the margin) allowed us to estimate 18 pairs with territories along $245 \mathrm{~km}$ sampled. Assuming the same density in the $31 \mathrm{~km}$ of river that was not navigable, which would hold two pairs, there would be a total of 20 pairs along $276 \mathrm{~km}$ of the Xingu River. Three nests in the area of the Intermediate Reservoir, found during vegetation suppression far from the river (8.5-10.9 $\mathrm{km}$ from left margin), were separated an average distance of $8.6 \mathrm{~km}(6.2-12 \mathrm{~km})$. For the Volta Grande area on the left margin up to the BR-230 using all records (nest and observations $>5 \mathrm{~km}$ from the margin) as center of the territories, there was a mean of $10 \mathrm{~km}$ between records, and the area would have been occupied by about 10 pairs (Figure 1).

Five Crested Eagle records allowed us to confirm territory overlap with Harpy Eagles. There was an average of $4.8 \mathrm{~km}$ (1.3-6.7 km, n=5) between active Harpy Eagle nests and Crested Eagle records. Also, within RAPELD modules $(n=5)$, the average distance between non-simultaneous records of the two species was $1.5 \mathrm{~km}(0.02-3.2 \mathrm{~km}, \mathrm{n}=11)$.

\section{Discussion}

The methods used in the present study allowed us to conclude that the Terrestrial RAPELD method for detecting Harpy Eagles and Crested Eagles appears to be more efficient in terms of distance travelled and time spent when compared to the effort from Aquatic standardized methods. Nevertheless, the aquatic effort was complementary in allowing estimates of the number of pairs in the region. It would be necessary the double the number of modules installed along the river to achieve the same information using only Terrestrial surveys. One application of results from the permanent Terrestrial Surveys database is the possibility of returning to the same sites (RAPELD modules) where breeding behavior was detected, or young were recorded (indicative of nest proximity), and further field work can be done using playback techniques, and using tree climbing for nest searches. This last tool is being used successfully in Atlantic Forest remnants in Espírito Santo state (Aguiar-Silva et al., 2012) and in Bahia state (Luz et al., 2006).

The average of $4.8 \mathrm{~km}$ between Harpy Eagle nests and Crested Eagle records was similar to the distance found in Ecuador (Muñiz-Lopez et al. 2007). The distance between the Harpy Eagle nest and Crested Eagle nest was $1.3 \mathrm{~km}$, much closer than the $2.3 \mathrm{~km}$ found in Ecuador (Muñiz-Lopez et al., 2007). They overlap territories and probably do not compete because Crested Eagles feed on smaller prey than Harpy Eagles (Sanaiotti et al., 2007; Soares et al., 2008; Whitacre et al., 2012; Gomes, 2014; Aguiar-Silva et al., 2011).

The average distance of $16 \mathrm{~km}$ between Harpy Eagle records along $276 \mathrm{~km}$ of the Xingu River allowed us to estimate the size of possible territories. Using each record as the territory center, gives an estimate of a maximum of 20 pairs along the surveyed extension of the Xingu River. This distance between nests is greater than expected, as $8 \mathrm{~km}$ apart is the average for another site in the same interfluve (Aguiar-Silva et al., 2011) and 3.8-6 km for Venezuela (Álvarez-Cordero, 1996). This greater distance between individuals results in a lower density, perhaps already a result of the lack of forest cover along the river. In a modeling study in Panama, the authors estimated a pair for every 2.6 or $6.2 \mathrm{~km}$, depending on the region (Vargas-González and Vargas, 2011). Gargett (1990) considered that distance between raptor nests reflects food availability. The mean distance $(8.6 \mathrm{~km})$ between nests in the Intermediate Reservoir area to be inundated 
was similar to that found for Pará state: $8 \mathrm{~km}$ (AguiarSilva et al., 2011).

Harpy Eagles are known to nest in managed forests (Álvarez-Cordero, 1996; Kung and Álvarez-Cordero, 1997; Aguiar-Silva et al., 2011), but the remnant forests along the Xingu River near Altamira are surrounded by pastures, which have expanded in the last 10 years (Escada et al., 2005). Forested areas within nesting territories are under pressure of being cut for pasture and timber extraction, leaving some territories only in narrow alluvial forest that will not be flooded with the filling of the Xingu Reservoir. The fauna of the region of the low-Xingu River will be subject to changes in species composition and abundance of prey species available to the Harpy Eagle due to the small flood pulse of the Belo Monte Dam (Aguiar-Silva et al., 2015). There is need for reserves on private land and, as suggested by Moura et al. (2014), we need to enforce current forest legislation and promote coordinated strategies across neighboring properties to safeguard regional biodiversity in the Amazon, including restoration of degraded forests.

The fact that a nest tree used in 2008 is still in use is a good indication that the pair is resident in the reproductive territory and will remain if not hunted and the nest tree continues to be surrounded by forest. The species shows resilience under disturbance (Álvarez-Cordero, 1996; Aguiar-Silva et al., 2014a, 2015). However, local extinction has been reported for some sites in the Amazon (Moura et al., 2014), indicating the need to maintain forest to guarantee foraging areas around the nest (Soares et al., 2008). Educational activities should be implemented with local communities and neighboring areas in a $20-30-\mathrm{km}$ radius around the nest. Incorporating community education outreach has been one of the tools used by the Panamanian Harpy Eagle Conservation Program (Curti and Valdez, 2009), and the PCGR in Brazil.

For two nests (Torrão and Module 1) the territories are not expected to flood, but the four active nests mapped during this study on the reservoirs (either Intermediate or Xingu) will be impacted. The territory and the juveniles still dependent on the nest will be isolated from the continuous forest by water. Although two of the nests are not expected to flood the bases of the trees, part of the surrounding forest will be lost to flooding. The other two nests that had already been isolated by vegetation removal will be completely inundated. The juveniles, which usually stay close to and use the nest for up two years (Muñiz-López et al., 2012), will suffer with the lack of perching trees. Thus, mitigation action of reinstalling perches near the forest remnant has been recommended (45b-Table 1). The two inactive nests, on islands downstream of the dam, will be subject to drastic decreases in the Xingu River flow, and the vegetated area is expected to decrease in size by $68 \%$ (Cunha and Ferreira 2012), with a presumed proportional decrease in territories of the pairs that made the nests.

Overall, of the 30 breeding pairs estimated to be in the sudy area, territories of 16 pairs will be partially or totally flooded, or subjected to drastic decrease in river flow, downstream of the dam. The remaining 14 territories have lost forest area to ranchers and are under threat of pasture expansion. Maintenance of the present density of Harpy Eagles will require active management.

\section{Acknowledgements}

We thank Avifauna Surveys and Terrestrial team EIA/RIMA 2000-2002 and 2007-2008. Aquatic Surveys and Wildlife Rescue teams 2012-2014, and authors of occasional records for sharing them. Special thanks to Denilson Aranha, Jailson Xavier from the RAPELD team; Rodolfo B Santos, Frederico A Raul and Igor Martins from the Rescue team; Vicente Medeiros, Dorinny Lisboa, Gregório Menezes, Roberta E Silva, Cesar Leite, Jose L Paula, Marcelo Ribeiro, Fredson Caitano and Ricardo V Leone from the Aquatic Avifauna and Mammal teams; Ralder F Rossi the Flora and Fauna Field Manager; Danielle A Silva, Cristiane RD Vieira, Bruna K Braun, Valderlan Conceição, Paulo Ferreira, Daniel Eskavron, Sebastião Rocha, Jose Pereira, Marcos Ramalho, Wanderley Eskavron, Alciomar Araujo, Elson Lima from the Rescue team; Carlos ED Cintra and Ismael Martins from CEA; Wesley Barella from Flora; José Pezzi from Ictiofauna. Rogério Miranda, Roberto Silva and Laurenz Pinder from Norte Energia. We thank Cesar A Silva for rescuing an injured Harpy Eagle, Emil Hernandez from UFPA-Altamira for transfering the eagle for care and CEA team for medical care. Carolina L Vanin and LC helped TMS with necropsy. Mauricio AM Soares provided a photograph of a hunted Harpy Eagle. Cicero Miranda and Jerson M. da Silva gave information about nests to FHAS. Sebastião Nascimento, George Matos, Elinaldo Viana and Rogério Clemente rescued the second injured Harpy Eagle and veterinarians from Systema Naturae/Arcadis Logos provided care. Olivier Jaudoin climbed and helped with nest monitoring. Carlos Chicarelli and Marcelo A dos Santos-Jr. assisted with the Figure. SV Wilson and WE Magnusson improved the English. Norte Energia S.A., Belo Sun Mineração and Systema Naturae/Arcadis Logos provided logistic support to FHAS during the release/monitoring of a Harpy Eagle at Projeto Volta Grande. Arcadis/Naturae provided logistic support to TMS during nest monitoring in the reservoirs. Local logistic support and nest monitoring in RAPELD and Torrão areas came from Biota. Air fares to TMS by INPA/VALE S.A./FDB. This study is part of goals 9 and 9.1 of PAN Low- and Mid-Xingu River-ICMBio, and contribution No. 5 of the Harpy Eagle Conservation Program (PCGR-Brazil).

\section{References}

AGUIAR-SILVA, FH., JUNQUEIRA, TG., SANAIOTTI, TM., GUIMARAES, VY., MATHIAS, PCV. and MENDONÇA, CV., 2015. Resource availability and diet of Harpy Eagle breeding territories on the Xingu River, Brazilian Amazon. Brazilian Journal of Biology. In press.

AGUIAR-SILVA, FH., LUZ, BB., SANAIOTTI, TM., JAUDOIN, O. and CABRAL, LD., 2011. Monitoramento da reprodução de 
gavião-real (Harpia harpyja) na Floresta Nacional do Tapajós PA. In Anais do I Seminário de Pesquisas Científicas da Floresta Nacional do Tapajós, 2011. Santarém. Santarém: Instituto Chico Mendes de Conservação da Biodiversidade-ICMBio. p. 89-97.

AGUIAR-SILVA, FH., SANAIOTTI, TM., JAUDOIN, O., SRBEK-ARAUJO, AC., SIQUEIRA, G. and BANHOS, A., 2012. Harpy Eagle sightings, traces and nesting records at the "Reserva Natural Vale", a Brazilian Atlantic Forest remnant in Espírito Santo, Brazil. Revista Brasileira de Ornitologia, vol. 20, no. 2, p. 62-69.

AGUIAR-SILVA, FH., SANAIOTTI, TM., JAUDOIN, O., LUZ, BB., MARTINS, FD., SOUSA, GL. and MILANO, MZ., 2013. Harpy Eagle nesting territories in Brazilian Forests, during the past 15 years. In Proceedings of the I Worldwide Raptor Conference, 2013. Bariloche. Bariloche: Universidad Nacional del Comahue.

AGUIAR-SILVA, FH., SANAIOTTI, TM. and LUZ, BB., 2014a. Food habits of the Harpy Eagle, a top predator from the Amazonian rainforest canopy. The Journal of Raptor Research, vol. 48, no. 1, p. 24-35. http://dx.doi.org/10.3356/JRR-13-00017.1.

AGUIAR-SILVA, FH., SANAIOTTI, TM., JAUDOIN, O., MARTINS, FD., VASCONCELOS, D. and PERES, VS., $2014 \mathrm{~b}$. Remoção e reintegração de gavião-real em área de conflito no Pará: conservação na Volta Grande do Rio Xingu. In I International Symposium and V Meeting of the Post-Graduate Program in Tropical Biodiversity. 2014. Macapá. Macapá: UNIFAP.

ÁLVAREZ-CORDERO, E., 1996. Biology and conservation of the Harpy Eagle in Venezuela and Panamá. Gainesville, FL: University of Florida. 212 p. Doctoral thesis in Philosophy.

Brasil. Ministério de Minas e Energia - MME, Empresa de Pesquisa Energética-EPE, 2011. Plano decenal de expansão de energia 2020. Brasília: MME/ EPE. Available from: <http://www. epe.gov.br/PDEE/20120302_1.pdf>. Access in: 03 Sept. 2015.

Brasil. Ministério do Meio Ambiente - MMA, Instituto Chico Mendes de Conservação da Biodiversidade - ICMBio, 2012. Portaria $n^{\circ}$ 16, 17 de fevereiro de 2012. Aprova o Plano de Ação Nacional para a Conservação das Espécies Endêmicas e Ameaçadas de Extinção da Fauna da Região do Baixo e Médio Xingu - PAN Baixo e Médio Xingu, estabelecendo espécies-alvo, sua abrangência geográfica, objetivo geral, objetivos específicos, formas de coordenação e supervisão. Diário Oficial da União, Brasília, 22 fev. Seção 1.

Brasil. Ministério do Meio Ambiente - MMA, Instituto Chico Mendes de Conservação da Biodiversidade - ICMBio, 2014a. Portaria $N^{o}$ 35, 27 de Março de 2014. Aprova o Plano de Ação Nacional para Conservação das Aves da Amazônia ameaçadas de extinção, PAN - Aves da Amazônia, contemplando quarenta e seis espécies, estabelecendo seu objetivo geral, objetivos especificos, ações, prazo de execução, abrangência e formas de implementação e supervisão. Diário Oficial da União, Brasília, 28 mar, Seção 1, p. 266.

Brasil. Ministério do Meio Ambiente - MMA, Instituto Chico Mendes de Conservação da Biodiversidade - ICMBio, 2014b. Lista brasileira da fauna ameaçada de extinção. Brasília: MMA/ ICMBio. Available from: <http:/www.icmbio.gov.br/portal/ biodiversidade/fauna-brasileira/lista-de-especies/5607-especie-5607. html>. Access in: 05 May 2014.

Brasil. Ministério da Ciência, Tecnologia e Inovação - MCTI, Ministério do Meio Ambiente-MMA, 2014c. PRODES. MCTI/ MMA. Available from: $<$ www.dpi.inpe.br/prodesdigital/prodes. php>. Access in: 10 Jan. 2014.
Convention on International Trade in Endangered Species of Wild Fauna and Flora-CITES, 2012. Appendices I, II and III. CITES. Available from: <http://www.cites.org/eng/app/index. shtml>. Access in: 20 Dec. 2012.

CUNHA, DA. and FERREIRA, LV., 2012. Impacts of the Belo Monte hydroelectric dam construction on pioneer vegetation formations along the Xingu River, Pará State, Brazil. Brazilian Journal of Botany, vol. 35, no. 2, p. 159-167. http://dx.doi. org/10.1590/S1806-99592012000200005.

CURTI, M. and VALDEZ, U., 2009. Incorporating community education in the strategy for Harpy Eagle conservation in Panama. The Journal of Environmental Education, vol. 40, no. 4, p. 3-15. http://dx.doi.org/10.3200/JOEE.40.4.3-16.

DELUCA, JJ., 2012. Birds of conservation concern in eastern Acre, Brazil: distributional records, occupancy estimates, humancaused mortality, and opportunities for ecotourism. Tropical Conservation Science, vol. 5, no. 3, p. 301-319.

EDWARDS, WH., 1847. A voyage up the river Amazon, including a residence at Pará. New York: Appleton \& Company. chap. XI, p. 121-124.

ESCADA, MIS., VIEIRA, ICG., KAMPEL, SA., ARAÚJO, R., VEIGA, JB., AGUIAR, APD., VEIGA, I., OLIVEIRA, M., PEREIRA, JLG., CARNEIRO-FILHO, A., FEARNSIDE, PM., VENTURIERI, A., CARRIELLO, F., THALES, M., CARNEIRO, TSG., MONTEIRO, AMV. and CÂMARA, G., 2005. Occupation processes in the new Amazonian frontiers: the Xingu/Iriri region. Estudos Avançados, vol. 19, p. 9-23. http://dx.doi.org/10.1590/ S0103-40142005000200002.

FEARNSIDE, P., 2006. Dams in the Amazon: Belo Monte and Brazil hydroelectric development of the Xingu River Basin. Environmental Management, vol. 38, no. 1, p. 16-27. http:// dx.doi.org/10.1007/S00267-005-0113-6.

FERGUSON-LEES, J. and CHRISTIE, DA., 2001. Raptors of the world. New York: Houghton-Mifflin Company. 992 p.

GARGETT, V., 1990. The Black Eagle: a study. London: Academic Press.

GOMES, FBR., 2014. Distribuição e ecologia do Uiraçu-falso (Morphnus guianensis, DAUDIN, 1800). Manaus: Instituto Nacional de Pesquisas da Amazônia. 129 p. Doctoral thesis in Ecology.

HENRIQUES, LMP., DANTAS, SM., SARDELLI, CH., CARNEIRO, LS., BATISTA, RSS., ALMEIDA, CCA., TORRES, MF., SILVA, MC., LARANJEIRAS, TO., MELLO FILHO, JC., 2008. Diagnóstico Avifaunistico da área de influencia do AHE BELO MONTE como subsídio ao estudo de impacto ambiental (EIA/RIMA). Manaus: INPA. vol. 27.

Instituto Brasileiro do Meio Ambiente - IBAMA, 2007. Termo de referência para elaboração do Estudo de Impacto Ambiental e o respectivo Relatório de Impacto Ambiental - EIA/RIMA aproveitamento hidrelétrico Belo Monte (PA). Pará.

International Union for Conservation of Nature - IUCN, 2014. IUCN Red List of Threatened Species. IUCN. Version 2012.1. Available from: <www.iucnredlist.org>. Access in: 20 Jan. 2013.

KUNG, P. and ALVAREZ-CORDERO, E., 1997. Raptor rescue: mapping Venezuela's harpy eagle habitat. GPS World, vol. 8, no. 7 , p. 22-32

LUZ, BB., 2005. Características de árvores utilizadas por Gaviãoreal (Harpia harpyja) para reprodução na Amazônia Brasileira. 
Manaus: Instituto Nacional de Pesquisas da Amazônia. 80 p. Masters Dissertation in Tropical Biology and Natural Resources.

LUZ, BB., AGUIAR-SILVA, FH. and SANAIOTTI, TM., 2010. Árvores utilizadas como local de reprodução de harpias são alvo de exploração madeireira. In Anais do $61^{\circ}$ Congresso Nacional de Botânica, 2010. Manaus. Manaus: INPA.

LUZ, BB., SANAIOTTI, TM., OLIVEIRA, DB. and COTES, M., 2006. Registro de ninho é esperança de manutenção de Harpias (Harpia harpyja) na Mata Atlântica. In: Anais do VI Congresso Internacional de Manejo de Fauna Silvestre na Amazônia e América Latina, 2006. Ilhéus. Ilhéus: UESC.

MAGNUSSON, WE., BRAGA-NETO, R., PEZZINI, F., BACCARO, F., BERGALLO, H., PENHA, J., RODRIGUES, D., VERDADE, LM., LIMA, A., ALBERNAZ, AL., HERO, J-M., LAWSON, B., CASTILHO, C., DRUCKER, D., FRANKLIN, E., MENDONÇA, F., COSTA, F., GALDINO, G., CASTLEY, G., ZUANON, J., VALE, J., SANTOS, J., LUIZÃO, RLC., CINTRA, R., BARBOSA, RI., LISBOA, A., KOBLITZ, RV., CUNHA, CN. and PONTES, ARM., 2013. Biodiversidade e monitoramento ambiental integrado. Santo André: Áttema Editorial. 351 p. Bilingual edition.

MAGNUSSON, WE., LIMA, AP., LUIZÃO, RC., LUIZÃO, F., COSTA, FRC., CASTILHO, CV. and KINUPP, VF., 2005. RAPELD: uma modificação do método de Gentry para inventários de biodiversidade em sítios para pesquisa ecológica de longa duração. Biota Neotropica, vol. 5, no. 2. Available from: $<$ http://www.biotaneotropica.org.br/v5n2/pt/abstract?point-ofview+bn01005022005>. Access in: 02 June 2014

MOURA, NG., LEES, AC., ALEIXO, A., BARLOW, J., DANTAS, SM., FERREIRA, J., LIMA, MF. and GARDNER, TA., 2014. Two hundred years of local avian extinctions in eastern Amazonia. Conservation Biology : the Journal of the Society for Conservation Biology, vol. 28, no. 5, p. 1271-1281. http://dx.doi.org/10.1111/ cobi.12300. PMid:24779443.

MUÑIZ-LÓPEZ, R., CRIOLLO, O. and MENDÚA, A., 2007. Results of five years of the "Harpy Eagle (Harpia harpyja) Research Program" in the Ecuadorian tropical forest. In BILDSTEIN, KL., BARBER, DR. and ZIMMERMAN, A. (Eds.). Neotropical raptors. Orwigsburg, PA: Hawk Mountain Sanctuary. p. 23-32.
MUÑIZ-LÓPEZ, R., RUBEN, L., CORTÉS, GD. and URIOS, V., 2012. Movements of Harpy Eagles Harpia harpyja during their first two years after hatching. Bird Study, vol. 59, no. 4, p. 1-6.

Norte Energia, 2014. Projeto Básico Ambiental: $5^{\circ}$ Relatório Consolidado de andamento do PBA e do atendimento de condicionantes, 2014. Brasília: Norte Energia. chap. 12.3.2. Available from: $<$ http://licenciamento.ibama.gov.br/Hidreletricas/ Belo\%20Monte/Relatorios $\% 20$ Semestrais/ $6 \% \mathrm{C} 2 \% \mathrm{BA} \% 20 \mathrm{RC} \% 20$ 310714\%20-\%20PDF/CAP\%C3\%8DTULO $\% 202 / 12 / 12.3 / 12.3 .2 /$ CAP\%202\%20-\%2012.3.2\%20-\%206\%C2\%BA\%20RC.pdf $>$. Access in: 05 Mar. 2015.

SANAIOTTI, TM., EREMILDES, J., SILVA, JJV., AGUIARSILVA, FH., LUZ, BB. and RODRIGUES, LF., 2007. Segundo registro de ninho de Morphnus guianensis para o Brasil. In $1^{\circ}$ Simpósio de Conservação na Amazônia; $20^{a}$ Semana de Biologia, 2007. Manaus. Manaus: UFAM.

SOARES, ES., AMARAL, FSR., CARVALHO FILHO, EPM., GRANZINOLLI, MA., ALBUQUERQUE, JLBL., LISBOA, JS., AZEVEDO, MAG., MORAES, W., SANAIOTTI, TM. and GUIMARÃES, IG., 2008. Plano de ação para conservação de aves de rapina - PANCAR. Brasília: ICMBio. 136 p. Série Espécies Ameaçadas, no. 5.

TRINCA, CT., FERRARI, SF. and LEES, AC., 2008. Curiosity killed the bird: arbitrary hunting of Harpy Eagles Harpia harpyja on an agricultural frontier in southern Brazilian Amazonia. Cotinga, vol. 30, p. 12-15.

VARGAS-GONZÁLEZ, JJ., WHITACRE, D., MOSQUERA, R., ALBUQUERQUE, J., PIANA, RP., THIOLLAY, J-M., MÁRQUEZ, C., SÁNCHEZ, JE., LÓPEZ, ML., MIDENCE, S., MATOLA, S., AGUILAR, S., RETTIG, N. and SANAIOTTI, TM., 2006. Estado y Distribución Actual del Águila Arpía (Harpia harpyja) en Centro y Sur América. Ornitologia Neotropical, vol. 17, p. 39-55.

VARGAS-GONZÁLEZ, JJ. and VARGAS, FH., 2011. Nesting density of Harpy Eagle in Darien with population size estimates for Panama. The Journal of Raptor Research, vol. 45, no. 3, p. 199-210. http://dx.doi.org/10.3356/JRR-10-57.1.

WHITACRE, DF., LÓPEZ, J. and LÓPEZ, G., 2012. Crested Eagle. In WHITACRE, DF. (Ed.). Neotropical birds of prey: biology and ecology of a forest raptor community. Ithaca: Cornell University Press. p. 164-184. 